\title{
The Relationship Of Knowledge With The Self-Management Of Diabetes Clients Diabetes Mellitus
}

\author{
Untung Halajur ${ }^{1}$, Irfan Setiawan ${ }^{2}$ \\ ${ }^{1 *}$ Dosen Jurusan Keperawatan Poltekkes Kemenkes Palangka Raya, \\ ${ }^{2}$ Alumnus Prodi DIV Keperawatan Poltekkes Kemenkes Palangka Raya \\ Corresponden Author : \\ *Email : untunghalajur65@gmail.com
}

\begin{abstract}
.
Knowledge or cognitive domain is very important for the formation of a person's actions. Knowledge is the main basis for treatment and prevention of diabetes perfect. Someone who has less knowledge about diabetes mellitus will be difficult to prevent the occurrence of diabetes and if a person suffering from diabetes with less knowledge will easily suffer complications of diabetes. Identifying Knowledge Relationships with Self-Management Patient Diabetes Militus in Poli Disease dr. Doris Sylvanus Palangkaraya. This research is quantitative questionnaires. The study design used in the form of cross-sectional analysis, the measurement and data collection only at one time.Measured variables, namely the relationship between knowledge as independent variables and self-management of diabetes mellitus as the dependent variable. Results of the analysis above shows respondents who have a good knowledge with good self-management (82.2\%). While knowledge is good with a poor self-management amounted to (17.8\%). The results of the analysis the table showed there (48.1\%) who had a poor knowledge with good self-management. While knowledge was poor with poor self-management amounted to (51.9\%). This study suggests knowledge of Diabetes Militus patients in Poli Disease dr. Doris Sylvanus Palangkaraya in getting significant value p-value of 0.002 or $<0.05$ that means there is a close relationship between knowledge and self-management of patients with diabetes mellitus.
\end{abstract}

Keywords: Knowledge, Diabetes Mellitus, Self-Management

\section{INTRODUCTION}

Diabetes mellitus according to the American Diabetes Association (ada) the year 2017 is a group of metabolic diseases with characteristic hyperglycemia that occurs because of abnormalities of insulin secretion, insulin action, or both. Some of the symptoms that are often found in patients with diabetes is polyuria, polydipsia, polyphagia, decrease weight, and blurred vision. Diabetes Mellitus is a group of metabolic disorders characterized by elevated levels of blood glucose (hyperglycemia) due to damage on the insulin secretion, insulin action or both (Brunner \& Suddarth, 2014)

Patients with Diabetes Mellitus in the world until the time this number is increasing. The World Health Organization (WHO) in 2016, said that the number of diabetics has increased from 108 million inhabitants in 1980 to 422 million people in the year 2014.THERE is 2016, sufferers of diabetes in the American population experienced an increase of 25.8 million residents in 2010 to 29.1 million inhabitants in 2012 . According to WHO (2000) estimated at least 171 million people worldwide suffer from Diabetes Mellitus or about $2.8 \%$ of the total population. The incidents continue to increase rapidly and is estimated to the year 2030 this figure reached 366 million people, or about $4.4 \%$ of the world population. Diabetes Mellitus are all over the world, the percentage of $90 \%$, which is a type of Diabetes Mellitus type 2 occur in developing countries, the increase in prevalence is the largest in Asia and in Africa. This is due to the trend of urbanization and lifestyle changes such as unhealthy eating patterns (WHO, 2012). 
Data from the Ministry of Health of the Republic of Indonesia (Moh RI), estimated in the year 2030 the prevalence of Diabetes Mellitus in Indonesia reached 21.3 million people. The results of Riskesdas 2013, the prevalence of diabetes mellitus based on the interviews there was an increase of $1.1 \%$ in 2007 to $2.1 \%$ in 2013 and diagnosed by a doctor as much as 1.5\%, the number of deaths due to Diabetes Mellitus in 2013 that as many as 5.1 million people, this number is higher when compared to deaths caused by HIV/AIDS (1.5 million people), tuberculosis ( 1.5 million people), and malaria (0.6 million people).The results of Riskesdas In 2018, the Prevalence of diabetes diagnosed by a doctor in West Kalimantan and Central Kalimantan $(1,1 \%)$, South Kalimantan (1.3 Percent), North Borneo (1.6 percent), and East Kalimantan (2.3 percent).

Department of Health Province of Central Kalimantan mention Diabetes Mellitus ranks fifth common diseases in the Province of Central Kalimantan after Typhoid fever, Diarrhoea, Hypertension, Influenza, namely by 7.254 people (Department of Health Province of Central Kalimantan, 2016). Report of the Health Department of the Province of Central Kalimantan of the year 2016 mentioned increased cases of patients with Diabetes Mellitus of 5.137 people in the year 2015 to be 7.254 people in the year 2016 .

Diabetes Mellitus in the city of Palangka Raya based on the Health Profile of the City of Palangka Raya (2017) is a disease not contagious in the top 10 common diseases, namely on the order of ninth. Preliminary studies that have been done in January 2019 in the poly of the disease in RSUD dr. Doris Sylvanus Palangka Raya,the results obtained that as many as 442 patient visits Diabetes Mellitus in January 2019.

The management of Diabetes Mellitus in order to prevent the occurrence of complications. The first step is done according to the Indonesian Endocrinology Association (PERKENI)year(2015)is by modifying to a healthy lifestyle, such as : medical nutrition therapy ( settings the amount, type, and feeding schedule ) and regular exercise. If necessary, a healthy lifestyle is also accompanied by interventions famakologis with the administration of the drug antihiperglikemia oral or insulin injection (PERKENI, 2015)

Patient knowledge about Diabetes Mellitus is an important means to help deal with diabetic patient itself, so that the more and the better knowledge about diabetes, then the better in dealing with diet Diabetes Mellitus (Gharaibeh \& Tawalbeh, 2018). Next change the behavior also will be able to control the condition of the disease, so can survive longer and the quality of life is getting better (Chai, et al., 2018).Research conducted by Riyambodo and Purwanti (2017) states that a person who has low knowledge tend to be difficult to accept and understand the information received, so that the person will be indifferent to new information and feel no need of that new information.

Knowledge or cognitive is the domain which is very important for the formation of a person's actions.Knowledge is the main basis for the treatment and prevention of diabetes perfect. Someone who has lack of knowledge about diabetes mellitus will be difficult to prevent the occurrence of Diabetes Mellitus and if a person suffering from Diabetes Mellitus with less knowledge will be easy to suffer from the complications of Diabetes Mellitus (Henry and Goddesses, 2016).

Patient knowledge about Diabetes Mellitus is a tool that can help patients run handling diabetes so the more and the better patients of Diabetes Mellitus learn about diabetes mellitus, and then can change his behavior.It can control the condition of the disease, so people with diabetes can live longer with a better quality of life (Soegondo, 2009).

Control of diabetes consists of four pillars, namely education, physical activity, diet therapy, and pharmacological treatment (Perkeni, 2015).Control of diabetes is required ability to manage daily life so that it can reduce the impact of the illness such as diabetes.It is called the self-management of diabetes. Behavior that reflects self-management in patients with diabetes, that a healthy diet, increase physical activity, use of diabetes medications routinely and regularly, monitoring blood glucose levels regularly, and do foot care as part of the education. Self-management of diabetes if done well, the four pillars of control of diabetes can be met (Daughters et al., 2013).

Perkeni (2011) states the management of diabetes mellitus consist of educational, nutritional therapy, medical, physical exercise, pharmacological intervention, and monitoring ketones and blood sugar. Blood sugar levels are affected by exercise, diet, lifestyle, medication/insulin therapy, genetic, obesity, age, and self management. Previous studies that previous researchers are researching about "the Relationship between Knowledge of Patients with Diabetes Mellitus Type 2 About Diabetes Complications Long-Term (chronic) 
Against the Motivation of Self Care, population and sample of previous researchers is patients with diabetes mellitus type 2, while the sample in this study conducted on all patients diagnosed with diabetes mellitus type 1 and type 2 .

The results of preliminary studies that have been done at week three January 2019 with Diabetes Mellitus by patients who have conducted interviews of 3 women and 2 men obtained the data that the level of knowledge about Diabetes Mellitus is relatively less, so that the self-management of Diabetes Mellitus patients poorly.The phenomenon above shows the level of knowledge has a close relationship with self-management in patients with Diabetes Mellitus. Lack of knowledge will negatively impact the self-management of patients with Diabetes Mellitus. Education is one of the indicators of the level of knowledge. In connection with the case then researchers did a study about "the Relationship of Knowledge with the Self-Management of Diabetes Mellitus In Patients with Diabetes Mellitus in the Poly of the Disease In RSUD dr. Doris Sylvanus Palangka Raya".

\section{METHODS}

This study is quantitative with questionnaires. The research design used in the form of analysis is cross sectional, that perform measurements and data collection at only one time. The variable that is measured, i.e. about the relationship between knowledge as the independent variable and self-management of diabetes mellitus as a dependent variable.

\section{DISCUSSION}

\section{Characteristics}

a. Age

A study of 100 respondents shows the results of that in table 4.1 the distribution of the results of the respondents age more found in the category adult age as many as 62 respondents $(62 \%)$. The same results are also contained in the research Rian Panelewen et al (2017) in the Clinic of Endocrine RSUP Prof. Dr. R. D Kandou Manado which shows that the majority of respondents aged 40-60 years (92,1\%). In line with the results of research conducted Kekenusa (2013) which shows that there is a meaningful relationship between age with the incidence of Diabetes Mellitus and stated that a person aged more than 45 years have a risk 8 times greater affected by the disease Diabetes Mellitus compared to those aged less than 45 years. Age is an influential factor because with increasing age, the ability of the organs of the body decreases.

b. Gender

The results showed the majority of respondents of male (51\%). This study is not in line denganAlghadir et al (2012) in Riyadh, saudi Arabia, states that women have a higher risk of developing diabetes compared with men.So also in a study conducted in Manado in 2012 stated that women are more likely to develop diabetes mellitus type 2 .

c. Education

The results of the study showed mayoriats respondents in this study had high SCHOOL and college respectively numbered 32 people (32\%). This is in line with research conducted by Hastuti (2008) about the risk factors of ulcer diabetika in patients with Diabetes Mellitus against the 72 respondents obtained a total of 49 respondents $(68 \%)$ with low education (ELEMENTARY school). The level of education has an influence on the incidence of the disease Diabetes Mellitus. People whose education levels are high will usually have a lot of knowledge about health. A high knowledge will make people have the awareness in maintaining health. In addition to knowledge, the level of education also affects the physical activity of a person because it is associated with the work done.People of high education level usually work in an office with little physical activity.People having low education levels is a lot to be laborers and farmers with sufficient physical activity or weight (Ariyanto, 2014). Research journal Of, et al (2014) stated that the educational background will shape the way of thinking of a person includes forming the ability to understand the factors related to the disease and use such knowledge to maintain health. This is supported by the statement Notoatmodjo (2007), the higher the level of education a person has, the higher his understanding, so that the level of education play an important role in the absorption and understanding of information. People who 
have a higher education level usually have knowledge about the health so will have the awareness in maintaining health (Mamangkey, Isabella $\mathrm{V}$ et al., 2013).

d. Self-Management Of Diabetes Mellitus

The results of the analysis of table 4.3 shows the majority of respondents who have self-good management as many as 73 respondents (73\%). The results of this study in line with research conducted by Daughters et al (2013) who stated that the results of the study showed almost all respondents $(90,4 \%)$ had information related to the disease Diabetes Mellitus. It becomes reasonable if on almost all aspects of behavior Self - Management of Diabetes Mellitus (SM Diabetes Mellitus) number of respondents by category of good is much more than the category of being nor bad. The results of this study in line with research Hampers et al (2004) which states that the behavior of the SM Diabetes Mellitus is influenced by the level of knowledge of respondents on Diabetes Mellitus S and its management.

\section{The Relationship Of Knowledge With Self-Management}

The results of the analysis of the relationship of knowledge with self - management use chi-square test with a confidence interval of $95 \%$ or a factor of chance is less than $5 \%(\alpha=0.05)$ to show a significant relationship. The results of the chi-square test results obtained $p$ value i.e., 0.002 to where it meets the $p$ value is $<\alpha$, it can be concluded there is a relationship of knowledge with the self-management of Diabetes Mellitus. Diabetes Mellitus type II is a disease associated with a sedentary lifestyle. A lot of people who have such a lifestyle rarely do physical activity,eat contain too much fat and sugar, and contains little fiber and carbohydrates. A lifestyle like this can be the main cause of up of diabetes.(Panggabean, 2008).

The results of this study are in line with previous research conducted by Jazillah (2003) where the relationship of knowledge and control of blood glucose levels showed a significant negative linear relationship with the closeness of the medium, which means that the higher the level of knowledge of respondents the more controlled blood glucose levels. Respondents who have low knowledge about the management of Diabetes Mellitus have a risk of glucose levels darahtidak controlled by 2.34 times compared with respondents who have high knowledge. Based on research conducted Rahmadiliyani and Abi root of the problem (2008) showed there is a significant relationship between knowledge about the disease and its complications in patients with Diabetes Mellitus by measures to control blood glucose levels. It is also in accordance with the opinion NotoaDiabetes Mellitus odjo (2010) who stated that one of the factors that determine the behavior of a person's health is knowledge.

\section{CONCLUSION}

The conclusion that can be drawn from the results of this study are as follows:

1. The results of the research based on the characteristics of demography Diabetes Mellitus showed that patients with Diabetes Mellitus in the Poly of the Disease In RSUD dr. Doris Sylvanus Palangka Raya is the majority based on age is found in many categories adult (62\%), male sex (51\%), high SCHOOLeducated and college berumlah (32\%), Private jobs amounted to $(52 \%)$.

2. The results of this study stated that patient knowledge of Diabetes Mellitus in Poly Disease In RSUD dr. Doris Sylvanus PalangkaRayamayoritas respondents who have a good knowledge amount (73\%).

3. The results of this study showed that Self - Management of Diabetes Mellitus in Poly Disease In RSUD dr. Doris Sylvanus Palangka Raya mayoitas of respondents who have self-management good amount (73\%).

4. The results of this study stated that patient knowledge of Diabetes Mellitus in Poly Disease In RSUD dr. Doris Sylvanus Palangka Raya in get a significant value of p-value to 0.002 or $<0.05$ artiya there is a close relationship between knowledge and self-management in patients with diabetes mellitus.

\section{REERENCE}

[1] American Diabetes Association (ADA). 2016. Standards of Medical Care in Diabetes-2017 Abridged for Primary Care Providers. Clinical Diabetes. 35(1):1-22.

[2] American Diabetes Association. 2017, Eye Complication, accessed 7 Juni 2020, Available at: http://www.diabetes.org/living-with-diabetes/complications/eye-complications 
[3] Budiman \& Riyanto, A., 2014.Kapita Selekta Kuesioner Pengetahuan dan Sikap Dalam Penelitian Kesehatan, Salemba Medika, Jakarta.

[4] Bustan, M. N.2007, Epidemiologi: Penyakit Tidak Menular, Rineka Cipta, Jakarta.

[5] Dhamayanti FA. 2018. Hubungan Manajemen Diri Diabetes Dengan Kontrol Gula Darah Pasien Diabetes Melitus Tipe II Pada Peserta Prolanis Di Bandar Lampung. Bandar lampung: Universitas Lampung.

[6] Ermawati Z. 2011. Gambaran Pengetahuan Dan Sikap Tentang Pengelolaan Penyakitnya Pada Penderita Diabetes Mellitus Di Rumah Sakit Umum Daerah Panembahan Senopati Bantul. Yogyakarta: Sekolah Tinggi Ilmu Kesehatan 'Aisyiyah.

[7] Efendy, F. \& Makhfudli.2009, Keperawatan Kesehatan Komunitas. Salemba Medika,Jakarta.

[8] Ernawati.2013, Penatalaksaan Keperawatan Diabetes Melitus Terpadu, Mitra Wacana Media, Jakarta.

[9] International Diabetes Federation.2015, IDF Diabetes Atlas Seventh Edition.available at: http://www.idf.org.

[10] Notoatmojo, S. 2012, Metodologi Penelitian Kesehatan, Rineka Cipta, Jakarta.

[11] Perkeni.2015, Konsensus Pengelolaan dan Pencegahan Diabetes Melitus Tipe 2 di Indonesia 2015, PB Perkeni, Jakarta.

[12] Perkumpulan Endokrinologi Indonesia (Perkeni).2015. Konsensus Pengelolaan dan Pencegahan Diabetes Melitus Tipe 2 di Indonesia 2015. Jakarta: PB. PERKENI.

[13] Putri DSR, Yudianto K, Kurniawan T. 2013. Perilaku Self-Management Pasien Diabetes Melitus (DIABETES MILITUS ). Jurnal Keperawatan. 1(1):30-38.

[14] Riskesdas. 2013. Riset Kesehatan Dasar (RISKESDAS) 2013. Jakarta: Badan Penelitian dan Pengembangan Kesehatan Kementerian Kesehatan RI.

[15] Riskesdas. 2018. Riset Kesehatan Dasar (RISKESDAS) 2018. Jakarta: Badan Penelitian dan Pengembangan Kesehatan Kementerian Kesehatan RI.

[16] Wawan A. dan Dewi M. 2016, Pengetahuan, Sikap, dan Perilaku Manusia, Nuha Medika, Yogyakarta. 